Counsellia: Jurnal Bimbingan dan Konseling, 9 (2), 2019| 127-136

Copyright (C2019 Universitas PGRI Madiun

ISSN: 2088-3072 (Print) / 2477-5886 (Online)

Available online at: http://e-journal.unipma.ac.id/index.php/JBK

DOI: $10.25273 /$ counsellia.v9i2.5186

\title{
Burnout Guru BK di Kota Singkawang
}

\author{
Insan Suwanto ${ }^{1}$, Slamat Fitriyadi ${ }^{2}$ \\ ${ }^{1}$ Bimbingan dan Konseling, STKIP Singkawang, Kota Singkawang \\ insansuwanto@gmail.com \\ ${ }^{2}$ Bimbingan dan Konseling, STKIP Singkawang, Kota Singkawang \\ ahmadfitriyadi521@gmail.com
}

\begin{abstract}
Abstrak
Tujuan dalam penelitian ini adalah untuk memberikan gambaran data ilmiah tentang bagaimana tingkat burnout pada guru bimbingan dan konseling (BK) yang ada di Kota Singkawang. Reponden dalam penelitian ini adalah seluruh guru BK kota singkawang pada SMP/sederajat dan SMA/sederajat se-Kota Singkawang. Penelitian ini merupakan descriptive survey research dengan menggunakan instrumen penelitian MBI-GS (Maslach Burnout InventoryGeneral Survey). Data dianalisis dengan menggunakan descriptive statistics. Hasil penelitian menunjukkan bahwa rata-rata guru BK di Kota Singkawang memiliki tingkat burnout yang sangat rendah (20,33\%). Hasil survei menunjukkan bahwa diantara 66 orang guru BK hanya 1 orang guru BK yang memiliki tingkat burnout Tinggi. Kemudian, 19 orang pada kategori Rendah, dan 46 orang masuk pada kategori Sangat Rendah. Berdasarkan survei, guru BK pria memiliki tingkat burnout yang lebih tinggi. Kemudian, Guru BK yang lebih muda dengan usia kerja kurang dari 10 tahun memiliki tingkat burnout yang lebih tinggi. Hal ini menunjukkan bahwa guru BK di kota singkawang sudah mampu menjalankan tugas dan perannya sesuai dengan yang seharusnya dan memiliki tingkat kepuasan kerja yang tinggi. Penelitian lebih lanjut diperlukan untuk mengetahui lebih lanjut tentang penyebab rendahnya burnout guru BK di Kota Singkawang.
\end{abstract}

Kata Kunci: Burnout, Guru BK

\begin{abstract}
The purpose of this study is to provide an overview of scientific data related to the level of burnout in the guidance and counseling (BK) teacher in Singkawang City. The respondents in this study were all guidance and counseling teachers in junior and high school in Singkawang City. This research is a descriptive survey research using the research instrument is the MBI-GS (Maslach Burnout Inventory-General Survey). Data were analyzed using descriptive statistics. The results showed that the average guidance and counseling teacher in Singkawang City had a very low burnout rate (20.33\%). The survey results showed that among 66 BK teachers only 1 guidance and counseling teacher had a high burnout rate. Then, 19 people were in a Low category, and 46 people were in the Very Low category. Based on the survey, male teachers have a higher burnout rate. Then, younger teachers with less than 10 years of age have
\end{abstract}


a higher burnout rate. Then, the guidance and counseling teacher in Singkawang City had a professional efficacy of 51.24\%. This shows that guidance and counseling teachers in the city of Singkawang have been able to carry out their duties and roles as they should and have a high level of job satisfaction. Further research is needed to find out more about the causes of the low guidance and counseling teacher burnout.

Keywords: Burnout, BK teacher

\section{PENDAHULUAN}

Guru bimbingan dan konseling (BK) mempunyai tugas, tanggung jawab, wewenang, dan hak secara penuh dalam kegiatan bimbingan dan konseling terhadap sejumlah pendidik. Guru BK dituntut untuk memiliki kemampuan untuk memahami siswa, memberikan pelayanan dan penyelesaian yang optimal kepada siswa. Namun, dalam pelaksanaannya belum optimal karena kekurangan yang terjadi pada Guru BK yang diakibatkan oleh kelelahan kerja (Burnout). Burnout merupakan keadaan dimana pikiran negatif dan terus-menerus yang berkaitan dengan pekerjaan, hal ini ditandai dengan kelelahan fisik, berkurangnya rasa kompetensi, penurunan motivasi, dan sikap disfungsional di tempat kerja (Gumbau \& Marisa, 2014).

Penyebab terjadinya burnout pada seseorang adalah karena kelebihan beban kerja, tidak adanya penghargaan, ada gangguan dalam kelompok kerja, tidak diberlakukan secara adil, dan terdapat tugas yang tidak sesuai dengan nilai-nilai (Maslach \& Michael, 1997). Salah satu penyebab munculnya burnout adalah kondisi lingkungan yang kurang baik dan ketidaksesuaian antara harapan pekerja dengan dukungan tempat bekerja (Christianty \& Lucia, 2016).

Tuntutan pekerjaan dan kehidupan dapat menghabiskan tenaga dan semangat kerja serta prestasi yang sulit untuk dicapai. Jika burnout pada seseorang dibiarkan maka dedikasi dan komitmen terhadap pekerjaan akan memudar. Burnout dapat memiliki dampak yang sangat buruk bagi kondisi kejiwaan dan kesehatan fisik. Selain itu, burnout dapat mengganggu kemampuan mengatasi masalah dan merusak gaya hidup sehat serta menurunkan kinerja pekerjaan. Burnout juga tidak berdampak pada diri sendiri, tetapi juga mempengaruhi orang disekitar, baik di tempat kerja maupun dirumah. Burnout bisa menyebabkan tekanan mental dalam bentuk kecemasan, depresi, dan gangguan tidur. Jika kelelahan dan perasaan negatif akibat burnout dibawa ke luar lingkungan kerja maka akan mempengaruhi hubungan dengan keluarga dan teman (Maslach \& Michael, 1997).

Setiap manusia dan pekerja dapat mengalami burnout di tempat kerja begitu juga dengan Guru Bimbingan dan Konseling (BK) di sekolah. Tuntutan pekerjaan dan kondisi lingkungan pekerjaan serta 
tuntutan untuk memahami kondisi dan keadaan siswa yang beragam menjadi masalah tersendiri bagi Guru BK. Faktor-faktor yang dapat menyebabkan burnout pada guru Bimbingan dan Konseling, yaitu fasilitas kerja, karakteristik klien, konflik antar karyawan, lingkungan kerja dan keterlibatan emosional dengan klien (Aufa, 2014).

Burnout pada Guru BK dapat terjadi karena faktor individu atau dari Guru BK itu sendiri. Selain itu burnout juga dapat terjadi karena kurangnya dukungan sosial dari lingkungan kerja. Semakin tinggi dukungan sosial yang di terima guru maka level burnout yang dialami semakin kecil (Purba, Aries, \& Ervy, 2007). Tetapi menurut Maslach \& Michael (1997) menyatakan dengan tegas bahwa burnout bukan berasal dari masalah individu tetapi dari lingkungan sosial tempat bekerja. Ketika tempat kerja tidak sesuai dengan pekerjaan manusia, maka risiko burnout tumbuh. Burnout yang dialami Guru BK yang berkelanjutan akan mengakibatkan kelelahan fisik dan mental.

Berdasarkan ringkasan masalah diatas, maka pertanyaan penelitian yang dikemukakan adalah bagaiamana tingkat burnout pada Guru BK yang ada di Kota Singkawang. Tujuan penelitian ini adalah untuk memberikan gambaran data ilmiah terkait tingkat burnout pada guru BK di Kota Singkawang.

\section{METODE PENELITIAN}

Dalam penelitian ini menggunakan penelitian descriptive survey. Penelitian survei merupakan salah satu prosedur penelitian yang sangat baik untuk mengukur sikap atau orientasi kelompok melalui jajak pendapat. Penelitian survei menjadi metode terbaik bagi peneliti sosial untuk mengumpulkan data guna menjelaskan gambaran populasi yang besar (Morisson, 2012). Oleh karena itu, didalam penelitian survei, data berupa angka-angka dikumpulkan oleh peneliti dan dianalisis secara statistik guna mendeskripsikan tanggapan dari responden dan menguji pertanyaan dari penelitian (Creswell, 2012).

Descriptive survey menjelaskan atau mencatat kondisi atau sikap yang ada saat ini (Morisson, 2012). Intinya yang hendak dicari peneliti adalah bagaimana anggota dari suatu populasi (Hamdi \& Baharuddin, 2014). Studi survei dalam penelitian ini bertujuan untuk memberikan gambaran data ilmiah terkait tingkat burnout pada guru BK di Kota Singkawang.

\section{Responden}

Dalam penelitian ini data dikumpulkan dengan cara sensus. Sensus adalah cara pengumpulan data bila seluruh elemen populasi diselidiki satu per satu (Sugiyono, 2016). Berdasarkan hasil sensus, adapun responden dalam penelitian ini adalah keseluruhan guru 
bimbingan dan konseling pada SMA/SMK/sederajat yang tersebar di tingkat SMP/MTs/sederajat dan Kota Singkawang.

Tabel 1. Jumlah Responden (Guru BK)

\begin{tabular}{cccc}
\hline Sekolah & Laki-laki & Perempuan & Jumlah \\
\hline SMP/Sederajat & 10 & 31 & 41 \\
SMA/Sederajat & 7 & 18 & 25 \\
\hline & Total & & 66 Orang \\
\hline
\end{tabular}

\section{Instrumen Pengumpulan Data}

Adapun instrumen yang akan digunakan dalam penelitian ini adalah MBI-GS (Maslach Burnout Inventory-General Survey). MBI-GS dilaporkan memiliki konsistensi internal yang tinggi (Marais, dkk., 2009) mulai dari 0,73 (Cynicism) hingga 0,91 (Exhaustion). Reliabilitas MBI-GS melalui Koefisien Alpha Cronbach juga dilaporkan tinggi (Coetzee \& Rothmann dalam Marais et al., 2009) dimana Exhaustion $(\alpha=0,85)$, Cynicism $(\alpha=0,70)$, Professional Efficacy $(\alpha=0,66)$. Komponen Exhaustion terdiri dari 5 item yang menggambarkan perasaan lelah, Cynicism terdiri dari 5 item yang menggambarkan ketidakpedulian atau sikap yang jauh mengenai pekerjaan seseorang, dan Professional Efficacy berisi 6 item yang menggambarkan perasaan sukses, prestasi, dan kompetensi secara umum pekerjaan seseorang (Hilton, 2017). Instrumen MBI-GS terdiri dari 16 item dan memiliki tiga indikator burnout (Exhaustion, Cynicism, Professional Efficacy).
Semua item dinilai pada skala penilaian tujuh poin, mulai dari 0 (tidak pernah) hingga 6 (setiap hari).

Kemudian, peneliti membuat kategorisasi dengan menetapkan beberapa kriteria. Kategorisasi dilakukan dengan kondisi jika data berdistribusi normal. Oleh karena itu, peneiliti menggunakan uji normalitas Kolmogorov-Smirnov dengan bantuan program IBM SPSS versi 20 dimana data akan memiliki distribusi normal jika $p \geq 0,05$.

Tabel 2. Hasil Tes Normalitas Data Kolmogorov-Smirnov

\begin{tabular}{ccc}
\hline $\boldsymbol{p}$ & df & Sig. \\
\hline 0,145 & 66 & 0,002 \\
\hline
\end{tabular}

Berdasarkan tabel di atas dapat diketahui nilai $p$ adalah 0,145 dengan nilai Sig. sebesar 0,002. Dikarenakan $p(0,145)$ dengan Sig. 0,002 > 0,05, maka data berdistribusi normal.

Berdasarkan perhitungan kriteria di atas, maka kategorisasi tingkat burnout adalah sebagai berikut: 
Tabel 3. Kategori Tingkat Bunrout

\begin{tabular}{llll}
\hline \multirow{2}{*}{ No } & Rentang & & \\
\cline { 2 - 3 } & Skor & Persentase & \\
\hline 1. & $73-96$ & $76 \%-100 \%$ & Sangat Tinggi \\
2. & $49-72$ & $51 \%-75 \%$ & Tinggi \\
3. & $25-48$ & $26 \%-50 \%$ & Rendah \\
4. & $0-24$ & $0 \%-25 \%$ & Sangat Rendah \\
\hline
\end{tabular}

\section{Analisis Data}

Dalam penelitian ini data dianalisis dengan statistik deskriptif (Descriptive Statistics). Statistik deskriptif adalah statistik yang digunakan untuk menganalisis data dengan cara mendeskripsikan atau menggambarkan data yang telah terkumpul (Sugiyono, 2017). Peneliti menggunakan statistik deskriptif untuk mengetahui data empiris tentang bagaimana tingkat burnout guru BK Kota Singkawang berdasarkan karakteristiknya yang relevan, seperti jenis kelamin, kelompok umur, dan kelompok usia kerja.

\section{HASIL DAN PEMBAHASAN}

Hasil Penelitian

Data dalam penelitian ini adalah data tentang tingkat burnout Guru BK se-Kota Singkawang. Berdasarkan pengumpulan dan analisis data, sehingga hasilnya sebagai berikut :

Tabel 4. Hasil Survei

\begin{tabular}{cccc}
\hline \multicolumn{2}{c}{ Rentang } & \multirow{2}{*}{ Kategori } & f \\
\cline { 1 - 2 } Skor & Persentase & & \\
\cline { 1 - 2 } $73-96$ & $76 \%-100 \%$ & Sangat Tinggi & 0 \\
$49-72$ & $51 \%-75 \%$ & Tinggi & 1 \\
$25-48$ & $26 \%-50 \%$ & Rendah & 19 \\
$0-24$ & $0 \%-25 \%$ & Sangat Rendah & 46 \\
\hline
\end{tabular}

Berdasarkan tabel di atas menunjukkan bahwa tidak ada guru BK yang tingkat burnout-nya Sangat Tinggi, namun hanya 1 orang guru BK yang memiliki burnout Tinggi.

Tabel 5. Tingkat Burnout Guru BK Kota Singkawang

\begin{tabular}{lccc}
\hline \multirow{2}{*}{ Sekolah } & \multicolumn{2}{c}{ Rata-rata } & \multirow{2}{*}{ f } \\
\cline { 2 - 3 } & Skor & Persentase & \\
\hline SMP/Sederajat & 18,34 & $19,11 \%$ & 41 \\
SMA/Sederajat & 21,44 & $22,33 \%$ & 25 \\
\hline
\end{tabular}


Berdasarkan tabel diatas lebih besar daripada Guru BK menunjukkan bahwa rata-rata tingkat SMP/sederajat.

burnout Guru BK SMA/sederajat

Tabel 6. Tingkat Burnout Guru BK Kota Singkawang Berdasarkan Jenis Kelamin

\begin{tabular}{lccc}
\hline \multirow{2}{*}{ Jenis Kelamin } & \multicolumn{2}{c}{ Rata-rata } & \multirow{2}{*}{ f } \\
\cline { 2 - 3 } & Skor & Persentase & \\
\hline Laki-laki & 22,12 & $23,04 \%$ & 17 \\
Perempuan & 18,61 & $19,39 \%$ & 49
\end{tabular}

Berdasarkan tabel diatas laki-laki lebih besar daripada Guru menunjukkan bahwa rata-rata tingkat BK perempuan. burnout Guru BK Kota Singkawang

Tabel 7 Tingkat Burnout Guru BK Kota Singkawang Berdasarkan Usia Kerja

\begin{tabular}{lccc}
\hline \multirow{2}{*}{ Usia Kerja } & \multicolumn{2}{c}{ Rata-rata } & \multirow{2}{*}{ f } \\
\cline { 2 - 3 } & Skor & Persentase & \\
\hline$<10$ Tahun & 20,33 & $21,18 \%$ & 27 \\
$10-20$ Tahun & 18,94 & $19,73 \%$ & 36 \\
$>$ 20 Tahun & 19,00 & $19,79 \%$ & 3 \\
\hline
\end{tabular}

Berdasarkan tabel diatas burnout yang lebih tinggi daripada menunjukkan bahwa rata-rata tingkat guru BK dengan usia kerja lebih dari Guru BK dengan usia kerja kurang 10 dan 20 tahun. dari 10 tahun memiliki tingkat

Tabel 8 Tingkat Burnout Guru BK Kota Singkawang Berdasarkan Umur

\begin{tabular}{lccc}
\hline \multirow{2}{*}{ Umur } & \multicolumn{2}{c}{ Rata-rata } & \multirow{2}{*}{ f } \\
\cline { 2 - 3 } & Skor & Persentase & \\
\hline < 30 Tahun & 21,60 & $22,50 \%$ & 5 \\
30 - 35 Tahun & 17,33 & $18,06 \%$ & 12 \\
36 - 40 Tahun & 19,89 & $20,72 \%$ & 38 \\
$>$ 40 Tahun & 19,64 & $20,45 \%$ & 11 \\
\hline
\end{tabular}

Berdasarkan tabel diatas menunjukkan bahwa rata-rata tingkat Guru BK dengan umur kurang dari 30 tahun memiliki tingkat burnout yang lebih tinggi daripada guru BK dengan usia lebih dari 30 tahun.

Selanjutnya, MBI-GS memiliki tiga indikator, yakni Exhaustion, Cynicism, dan Professional Efficacy. Adapun hasil analisis data tingkat burnout guru bk kota singkawang 
berdasarkan indikator adalah sebagai berikut :

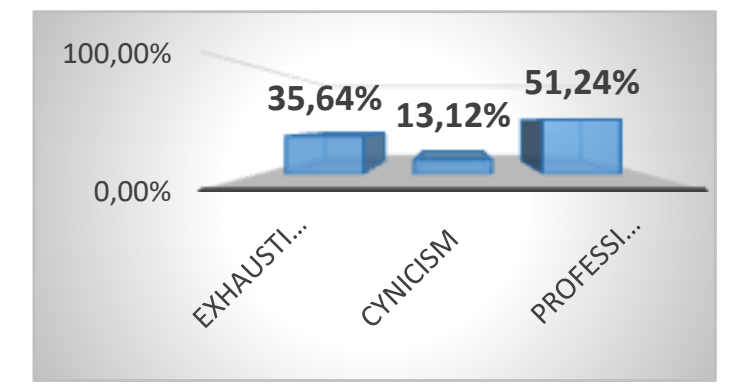

Diagram 1. Indikator Burnout Guru BK Singkawang

Berdasarkan grafik di atas dapat diketahui bahwa tingkat burnout guru BK Kota Singkawang pada indikator exhaustion sebesar $35,64 \%$, indikator cynicism sebesar $13,12 \%$, dan indikator professional efficacy sebesar 51,24\%. Hal ini menunjukkan bahwa guru BK di Kota Singkawang sudah menjalankan perannya sesuai dengan yang seharusnya dan memiliki tingkat kepuasan kerja yang tinggi.

\section{Pembahasan}

Kondisi, beban dan tuntutan pekerjaan menjadi masalah tersendiri bagi Guru BK hingga dapat menyebabkan burnout pada guru BK. Namun, berdasarkan hasil penelitian yang telah dilakukan, diperoleh data bahwa guru bimbingan dan konseling di Kota Singkawang memiliki tingkat burnout yang sangat rendah. Hal ini berarti bahwa guru bimbingan dan konseling yang ada di Kota Singkawang memiliki kepuasan kerja yang tinggi sebagai guru bimbingan dan konseling (BK) di sekolah. Hal ini berbeda dengan penelitian Gündüz, dkk. (2012) dimana guru BK memiliki skor depersonalisasi yang tinggi.

Berdasarkan hasil penelitian bahwa tingkat burnout guru BK Kota Singkawang pada indikator professional efficacy sebesar 51,24\%. Hal ini mengindikasikan bahwa guru BK Kota Singkawang merasa puas dengan kinerjanya sebagai guru BK. Seseorang dengan tingkat kepuasan kerja tinggi dapat menunjukkan sikap positif terhadap kerja (Robbins, 2006). Tingginya indikator professional efficacy dapat disebabkan oleh beberapa aspek yang mungkin mempengaruhi. Seorang menjadi puas atau tidak puas dari suatu pekerjaan, yaitu karena pekerjaan itu sendiri, gaji, kesempatan promosi, pengawasan, dan rekan kerja (Luthans, 2006).

Hasil penelitian ini juga menunjukkan bahwa rata-rata tingkat burnout Guru BK Kota Singkawang laki-laki lebih besar daripada Guru BK perempuan. Terdapat beberapa temuan yang menunjukkan bahwa burnout berdasarkan perbedaan jenis kelamin dimana wanita lebih rentan terkena tekanan dibandingkan pria. 
Menurut penelitan Rubino, dkk. (2013) bahwa kelelahan emosional pada wanita cenderung lebih tinggi daripada pria. Selanjutnya, level burnout guru laki-laki wanita tidak jauh berbeda dengan guru perempuan (Brewer \& Shapard, 2004). Burnout lebih sering terjadi pada perempuan, beberapa pada lakilaki, dan beberapa tidak ada perbedaannya (Garner, dkk., 2007). Oleh karena itu, hasil studi mengenai tingkat burnout pada jenis kelamin cenderung tidak konsisten dan bervariasi. Sehingga, diperlukan studi lebih lanjut pada hal-hal yang memengaruhi burnout pekerja (Rubino, dkk., 2013).

Kemudian, hasil penelitian ini juga menunjukkan bahwa rata-rata tingkat Guru BK dengan usia kerja kurang dari 10 tahun memiliki tingkat burnout yang lebih tinggi daripada guru BK dengan usia kerja lebih dari 10 dan 20 tahun. Ini artinya guru BK yang telah lama bekerja telah mampu mengelola kelelahan kerja lebih baik, Namun hal ini berbeda dengan studi Demerouti, dkk. (2005) dimana pekerja yang senior memiliki tingkatan burnout yang lebih tinggi.

Selanjutnya, hasil penelitian ini menunjukkan bahwa rata-rata tingkat Guru BK dengan umur kurang dari 30 tahun memiliki tingkat burnout yang lebih tinggi daripada guru BK dengan umur lebih dari 30 tahun. Hal ini menunjukkan bahwa pekerja yang lebih tua dianggap lebih mampu dalam menangani burnout. Menurut Aloe, dkk. (2014) Burnout terjadi lebih tinggi pada guru yang masih muda dan lebih berisiko mengalami burnout. Selain itu, menurut (Sunbul, 2003) pekerja dengan usia muda cenderung menunjukkan skor burnout \& anxiety yang lebih tinggi daripada pekerja yang lebih tua.

Penelitian ini diharapkan dapat menjadi penelitian awal dalam mengungkap fenomena burnout pada guru BK Khususnya tentang faktorfaktor yang mempengaruhi rendahnya burnout pada guru BK di Kota Singkawang. Mempertimbangkan tuntutan tugas dan tanggung jawab profesi guru BK atau konselor yang tinggi, sebab profesi Guru BK lebih berisiko terhadap burnout. Hal ini disebabkan karena guru BK sering berhadapan dengan tuntutan emosional dari siswanya (Bahrer-Kohler, 2012). Maka penelitian ini menjadi penting bagi pengembangan profesi guru BK atau konselor agar dapat menghindari burnout dan dapat berperan aktif dalam pembentukan diri menjadi individu yang produktif dalam kegiatan pelayanan bimbingan dan konseling.

\section{SIMPULAN}

Terima kasih kami ucapkan kepada Direktur Riset dan Pengabdian Masyarakat (DRPM) Kementerian Riset, Teknologi, dan Pendidikan Tinggi yang telah 
mendanai penelitian ini. Hasil penelitian menunjukkan bahwa Guru BK di sekolah tingkat SMP dan SMA Kota Singkawang memiliki tingkat burnout yang sangat rendah. Dimana guru BK pria memiliki tingkat burnout yang lebih tinggi. Kemudian, Guru BK yang lebih muda dengan usia kerja kurang dari 10 tahun memiliki tingkat burnout yang lebih tinggi. Hal ini menunjukkan bahwa guru BK di kota singkawang sudah mampu menjalankan tugas dan perannya serta dapat menyesuaikan diri dengan kondisi lingkungan kerja dengan baik.

\section{DAFTAR PUSTAKA}

Aloe, A. M., Amo, L. C., \& Shanahan, M. E. (2014). Classroom management self-efficacy and burnout: a multivariate metaanalysis. Journal Educational Psychology Review, 26(1).

Aufa, A. (2014). Upaya Preventif Guru Bimbingan dan Konseling Terhadap Terjadinya Burnout. Jurnal Hisbah, 11(1).

Bahrer-Kohler, S. (2012). Burnout for Expert: Prevention in the context of living and working. London: Springer Science \& Business Media.

Brewer, E. W., \& Shapard, L. (2004). Employee Burnout: A MetaAnalysis of the Relationship Between Age or Years of Experience. Sage Publication of Human Resources Development Review, 3(2).

Christianty, T. O. V., \& Lucia, T. W. (2016). Burnout Ditinjau Dari Employee Engagement Pada Karyawan. Psikodimensia, 15(2).

Creswell, J. W. (2012). Research design
Pendekatan kualitatif, Kuantitatif dan Mixed; Cetakan ke-2. Yogyakarta: Pustaka Pelajar.

Demerouti, E., Verbeke, W. J. M. I., \& Bakker, A. . (2005). Exploring the relationship between a multidimensional and multifaceted burnout concept and self-rated performance. Jurnal Management, $31(2)$.

Garner, B. R., Knight, K., \& Simpson, D. D. (2007). Burnout among corrections-based drug treatment staff. Journal Comparative Criminology, 51(5).

Gumbau, S. L., \& Marisa, S. S. (2014). Loss and Gain Cycles? A Longitudinal Study about Burnout, Engagement, and Self-Efficacy. Journal Burnout Research, 1(1).

Gündüz, H. Ç., Günsel, A., \& Ulutaş, T. (2012). Effects Of Emotional Intelligence On Job Satisfaction: An Empirical Study On Call Center Employees. Procedia -Social and Behavioral Sciences, 58.

Hamdi, A. S., \& Baharuddin, E. (2014). Metode Penelitian Kualitatif. Yogyakarta: Deepublish.

Hilton, T. (2017). Study Results: Effect of Burnout on Clinical Lab Turnover Intention. MedicalLab Management, 6(5).

Luthans, F. (2006). Perilaku Organisasi (Terjemahan). Yogyakarta: Andi.

Marais, C., Mostert, K., \& Rothmann, S. (2009). The psychometrical properties of translated versions of the Maslach Burnout Inventory General Survey. Journal of Industrial Psychology, 35(1).

Maslach, C., \& Michael, P. L. (1997). The Truth About Burnout. San Francisco: Jossy Bass.

Morisson. (2012). Metode Penelitian Survei. Jakarta: Kencana.

Purba, J., Aries, Y., \& Ervy, W. (2007). Pengaruh Dukungan Sosial Terhadap Burnout Pada Guru. Jurnal Psikologi, 5(1). 
Robbins, S. . (2006). Perilaku Organisasi (10th ed.). Jakarta: Indeks Kelompok Gramed.

Rubino, C., Volpone, S. D., \& Avery, D. . (2013). Burnout on mars and venus: exploring gender differences in emotional exhaustion. Journal Gender in Management, 28(2).

Sugiyono. (2016). Metode Penelitian Kuantitatif, Kualitatif, dan Kombinasi (Mixed Methoods). Bandung: Alfabeta.

Sugiyono. (2017). Metode Penelitian Kuantitatif, Kualitatif dan $R \& D$. Bandung: Alfabeta.

Sunbul, A. M. (2003). An analysis of relations among locus of control, burnout and job satisfaction in Turkish high school teachers. Australian Journal Education, 47(1). 